African Crop Science Journal, Vol. 24, No. 4, pp. 405 - 416 Printed in Uganda. All rights reserved
ISSN 1021-9730/2016 \$4.00

(C) 2016, African Crop Science Society

African Crop Science Journal by African Crop Science Society is licensed under a Creative Commons Attribution 3.0 Uganda License. Based on a work at www.ajol.info/ and www.bioline.org.br/cs DOI: http://dx.doi.org/10.4314/acsj.v24i4.7

\title{
MECHANISM FOR POLLINATION IN AFRICAN YAM BEAN
}

\author{
O.B. OJUEDERIE ${ }^{1,2}$, M.O. BALOGUN ${ }^{1}$ and M.T. ABBERTON ${ }^{3}$ \\ ${ }^{1}$ Department of Crop Protection and Environmental Biology, University of Ibadan, Nigeria \\ ${ }^{2}$ Department of Biological Sciences, Bells University of Technology, Ota, Nigeria \\ ${ }^{3}$ Genetic Resources Center, International Institute of Tropical Agriculture, Ibadan, Nigeria \\ Corresponding author: omenabernojus@gmail.com
}

(Received 15 January, 2016; accepted 7 November, 2016)

\begin{abstract}
African yam bean (AYB) (Sphenostylis stenocarpa (Hochst Ex. A. Rich) Harms is a neglected and underutilised legume in tropical Africa. Its utilisation has been hampered by the presence of anti-nutritional factors and lack of improved varieties. The objective of this study was to investigate pollination and determine the rates of selfing and outcrossing in the species. Accession TSs5 had the highest fruit set $(63.16 \%)$ in the open-pollinated breeding method; while AYB50 had the lowest value (46.61\%). Seed set in the selfed accessions ranged from $91.45 \%$ (AYB50) to $94.97 \%$ (TSs66). Fruit set was highest in the open-pollinated breeding method, with a mean average fruit set of $51.32 \%$. Significant differences $(\mathrm{P}<0.01)$ were obtained in fruit set from accessions isolated with net bags which had the lowest seed set (88.91\%) Seed set was highest (92.92\%) in the selfed accessions. The self incompatibility index ranged from 1.33 to 2.26 and the rate of fruit set from artificial self-pollination was greater than $30 \%$ in the field, and the screen house showing that the species is highly self compatible. Selfing and outcrossing rates of 91.38 and $8.62 \%$ showed that $S$. stenocarpa is not an obligate selfer. AYB sets fruits and seeds when open pollinated, isolated, selfed or crossed with other accessions.
\end{abstract}

Key Words: Emasculation, self incompatibility, underutilised legume, Sphenostylis stenocarpa

\section{RÉSUMÉ}

La légumineuse igname de l'Afrique (AYB) (Sphenostylis stenocarpa (Hochst Ex. A. Rich) Harms est une légumineuse négligée et sous utilisée en Afrique tropicale. Sa teneur en substances toxique et le manque de variétés améliorées constituent un frein pour son utilisation massive. Il a été ici question d'étudier sa pollinisation et de déterminer les taux de pollinisation croisée et auto-pollinisation dans l'espéce. L'accession TSs5 avait le nombre de gousses le plus élevé $(63,16 \%)$ sous pollinisation ouverte, tandis que l'accession AYB50 a exhibé la valeur la plus faible (46,61\%). Les nombres de gousses sous auto pollinisation variaient de 91,45\% (AYB50) à 94,97\% (TSs66). Ce nombre était plus élevé sous pollinisation ouverte, avec une moyenne de 51,32\%. Des differences significatives $(\mathrm{P}<0.01)$ ont été observées dans les nombres de gousses chez les accessions protégées par des filets et qui avaient les plus faibles nombres de grains $(88,91 \%)$. Le nombre de grains le plus élevé $(92,92 \%)$ était observé par auto pollinisation. L'indice de d'auto incompatibilité était de 1,33 à 2,26 et le taux de fructification chez les plantes artificiellement auto pollinisées était supérieur à $30 \%$ dans le champs, et en serre, indiquant ainsi que l'espèce est hautement auto compatible. Les taux d'auto pollinisation 91,38 et de pollinisation croisée 8,62\% montrent que l'auto pollinisation chez $S$. stenocarpa n'est pas obligatoire. AYB produit des gousses et graines sous toutes forms de pollinisation.

Mots Clés: Emasculation, auto incompatibilité, légumineuse sous utilisée, Sphenostylis stenocarpa 


\section{INTRODUCTION}

African yam bean (AYB), (Sphenostylis Stenocarpa (Hochst Ex. A. Rich) Harms, the most economically important among the seven species of Sphenostylis, is a leguminous herbaceous climbing vine, common to tropical Africa (Potter, 1992). Despite its nutritional benefit (Chinedu and Nwiniyi, 2012; Adewale et al., 2013), AYB still remains a neglected and underutilised crop in Africa. The presence of anti-nutritional factors such as oxalate, phytate, lectin, saponin, tannin, trypsin inhibitors and hydrogen cyanide; along with the long time taken to cook (Fasoyiro et al., 2006), and low seed yield (Saka et al., 2004) have adversely discouraged its production and largescale commercialization. Lack of improved varieties with dwarf erect architecture and shorter growth periods being additional reasons (Klu $e t$ al., 2001).

In order to improve any plant species, the knowledge of reproductive biology is indispensable. A highly diverse array of breeding methods has evolved in flowering plants, from obligate cross-fertilisation to obligate or promoted self-fertilisation, with each strategy presenting selective advantages and disadvantages (Takebayashi and Morrell, 2001). Flower production, pollen fertility, duration of flowering and pod and seedset potentials are important factors that determine the reproductive capacity of plants (Togun and Egunjobi, 1997). Legumes offer an interesting opportunity to evaluate how self-compatibility, the outcrossing rate and inbreeding depression interact; most annual legumes reproduce through a combination of selfing and outcrossing (Karoly, 1992; Kittleson and Maron, 2000).

Despite numerous studies on the mating system of annual legumes, only few have examined the levels of self-compatibility and the outcrossing rate in AYB. Popoola et al. (2011) described the flowers of AYB as cleistogamous, which open late in the evening or early in the morning; and closes before noon. They described it as an obligate selfer; while Adewale (2011) observed approximately $90 \%$ selfing and $10 \%$ outcrossing in AYB; indicating that AYB demonstrates both self and cross pollination. This study addressed the topic of pollination mechanisms and successes in AYB.

\section{MATERIALS AND METHODS}

Site and plant materials. The seeds of AYB used in this study were obtained from the Genetic Resources Centre of the International Institute of Tropical Agriculture Ibadan (IITA) at Ibadan (TSs5, TSs45 and TSs154) and the Institute of Agricultural Research and Training, (IAR\&T) Moor Plantation, Ibadan (AYB45 and AYB50). The study was conducted in the experimental field of IITA at as well as in a screen house of IITA (lat $7^{\circ} 29^{\prime} 56^{\prime \prime} \mathrm{N}$, long $3^{\circ} 54^{\prime} 27.42^{\prime}$ E' and alt $239.27 \mathrm{~m}$ asl).

Field experiment. The pollination mechanism of AYB was determined under natural field conditions, using the approach suggested by Dafni (1992). Three pairs of accessions (total of 6 parents) were chosen with extreme values for days to $50 \%$ flowering, seed length, seed width, and 100 seed weight, respectively, in accordance with the method of Adewale (2011). Seeds of six accessions TSs5 (Agate brown seeds), TSs45 (mottled seeds), TSs66 (purplish grey seeds), TSs 154 (brown seeds), AYB50 and AYB4 (mottled seeds) were planted on ridges at one meter interand intra- row spacing. Each accession had a population of fifteen plants, five plants per replication (per row) and one plant was maintained per stand. The experimental design used was a randomised complete block design, with three replicates.

Screen house experiment. Sterilised top soil was sieved to obtain loose, aerated, uniform soil structure. Ninety pots with perforations beneath them; each measuring $19.0 \mathrm{~cm} \times 15.5 \mathrm{~cm} \times 15.5 \mathrm{~cm}$ were filled with sterilised soil. Soil was watered and three seeds per pot were planted and thereafter thinned to one seedling after emergence. Each of the six AYB accessions had fifteen pots, five pots per replication. The experiment design used was a completely randomised design with three replicates. 
Cross and self-pollination. The intra- and intergenotypic compatibility of AYB accessions was determined by taking three pairs of accessions (TSs5 and AYB50; TSs45 and TSs66 and TSs154 and AYB4) with extreme values for days to $50 \%$ flowering, seed length, seed width, seed thickness, and 100 seed weight, respectively (Adewale, 2011). Three plants per row of each accession were marked and labeled as A, B, C, D and E, replicated thrice (Fig. 1).

Plant A = unemasculated flowers, left for openpollination;

Plant B = emasculated flowers, crossed with pollen grains from another genotype;

Plant $\mathrm{C}=$ unemasculated flowers enclosed (isolated) with fine mesh transparent net before flowering commences and throughout the flowering period to prevent contacts with foreign pollens and insects;

Plant D = emasculated flowers, crossed with pollen grains from the same genotype; and

Plant $\mathrm{E}=$ emasculated flowers not pollinated with pollen grains.

Mature flower buds were emasculated in the evening (5:00- $6: 30 \mathrm{pm})$ by removing the free and exposed anthers carefully, with a pair of forceps, which was intermittently dipped in methylated spirit during emasculation and pollination to prevent contamination (Frankel and Galum, 1977). The flowers were hand pollinated the following morning, by dusting pollen grains from male parents on the stigma of the emasculated female parents. Reciprocal crosses were made for all the accessions.

Data analysis. Experimental plants were checked for fruit set at the end of the reproductive season and the percentage seed set determined using the formula:

Number of seeds per pod x 100 Number of locules per pod
Fruit-set for each accession was defined as the percentage of fruit to the pollinated flowers at the end of the reproductive cycle.

Paired T-test statistics was used to compare the means of the fruit set and seed set percentages between $\mathrm{A}$ and $\mathrm{B}$, and $\mathrm{C}$ and $\mathrm{D}$ in all possible combinations.

Index of Self incompatibility (ISI) was estimated as the ratio between fruit set obtained by hand self-pollination and that obtained by hand cross-pollination (Dafni, 1992).

Where self fruit set and cross fruit-set are data obtained from controlled pollination experiments. The selfing rate (S) was estimated according to Charlesworth and Charlesworth (1987) as:

$$
S=\text { Pxfd }- \text { Po/Pxfd }- \text { Psfd }
$$

Where:

Pxfd = the value from crossing on the field, Psfd $=$ the value from selfing on the field , and Po $=$ the value from open pollination.

The outcrossing rate was determined by the equation of Karron (1987) as

$\mathrm{T}=1-\mathrm{S}$

Where: $\mathrm{T}=$ the outcrossing rate and $\mathrm{S}$ is the selfing rate.

Seeds from the four categories of fruits (i.e., A, $\mathrm{B}, \mathrm{C}$ and $\mathrm{D}$ ) were assessed in a germination test, which are recommended reliable tests for determining the reproductive success of crops (Dafni, 1992). Germination test was carried out on the seeds set obtained from the four breeding methods evaluated in accordance with the method in the standard operation procedures for Seed bank IITA (IITA, 2012). This was carried out in the laboratory at room temperature $\left(25-30^{\circ}\right.$ C). Twenty seeds of each accession were coated with mancozeb before being plated in sterilised germination transparent polyethylene rectangular boxes $(170 \mathrm{~mm} \times 110 \mathrm{~mm} \times 50 \mathrm{~mm})$ lined with moistened germination paper in three replications. The experiment was left at the germination stand for ten days, after which the 

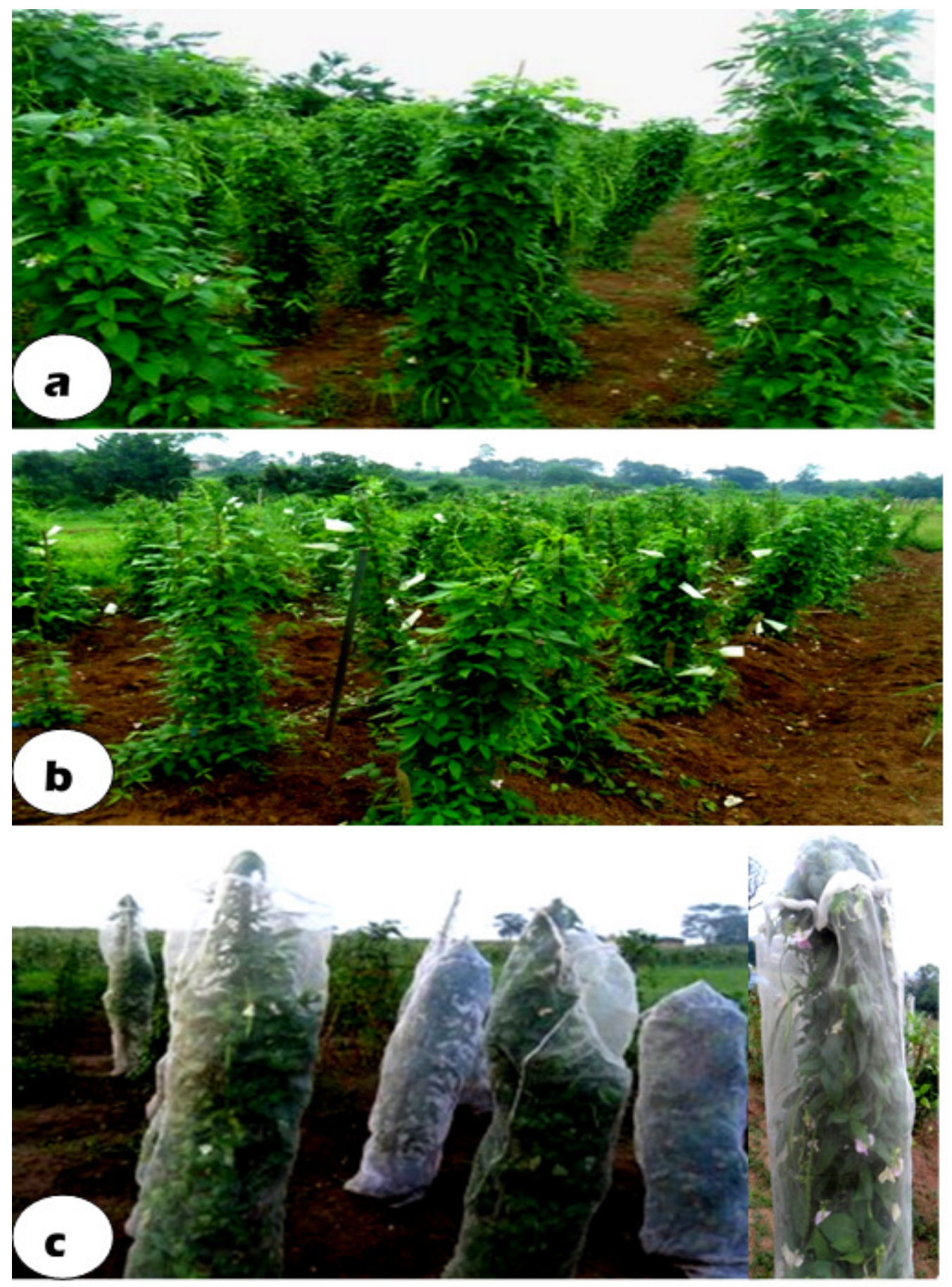

Figure 1. Pollination mechanism (a) open pollinated, (b) Crossed and selfed accessions, and (c) isolated 
sprouted seeds were counted and vigour for each breeding system recorded through the following.

Germination \% = Number of germinated seeds/ total seeds planted $\mathrm{x} 100$

Vigour $\%=$ Number of health seedlings/Number of seeds planted x 100

One way ANOVA was performed in order to compare the fruit set of accessions in the four pollination methods and means with significant differences separated using Student-NewmanKeuls -SNK The data were described as mean \pm SD. The results were analyzed using SAS Version 9.3 software (SAS, 2010).

\section{RESULTS}

Fruit and seed set. Flowering occurred and fruits and seeds were set on plants in the four pollination categories of plants tagged A - D. No fruits or seeds were set in category $\mathrm{E}$. The number of attempted crosses and corresponding successes achieved for the five categories of pollination in the six AYB accessions are presented in Table 1. The highest fruit set percentage (FSP) of the accessions left for open pollination was obtained in TSs5, while AYB50 had the least. The average FSP obtained was $51.32 \%$ in the open pollination experiment, which was higher than that obtained in other categories (Table 2). The FSP obtained from accessions isolated with fine nylon mesh net bags were significantly different $(\mathrm{P}<0.01)$ from other categories of pollination. The average FSP was lower in the flowers from isolated accessions than those left for open pollination.

The fruit set obtained when accessions were self-pollinated ranged from $38.25 \%$ (TSs66) to $43.62 \%$ (TSs5) on the field, and 31.39\% (TSs45) to $53.89 \%$ (TSs 154) in the screen house. Similarly, the fruit set obtained when two different accessions were crossed in the field and in the screen house ranged from $18.55 \%$ (TSs 154) to $30.76 \%$ (AYB4), and from $42.12 \%$ (TSs154) to $47.04 \%$ (AYB50), respectively. The results of the seed set for the four pollination methods in the field and the selfing and crossing in the screen house, are presented in Table 3. The seed set

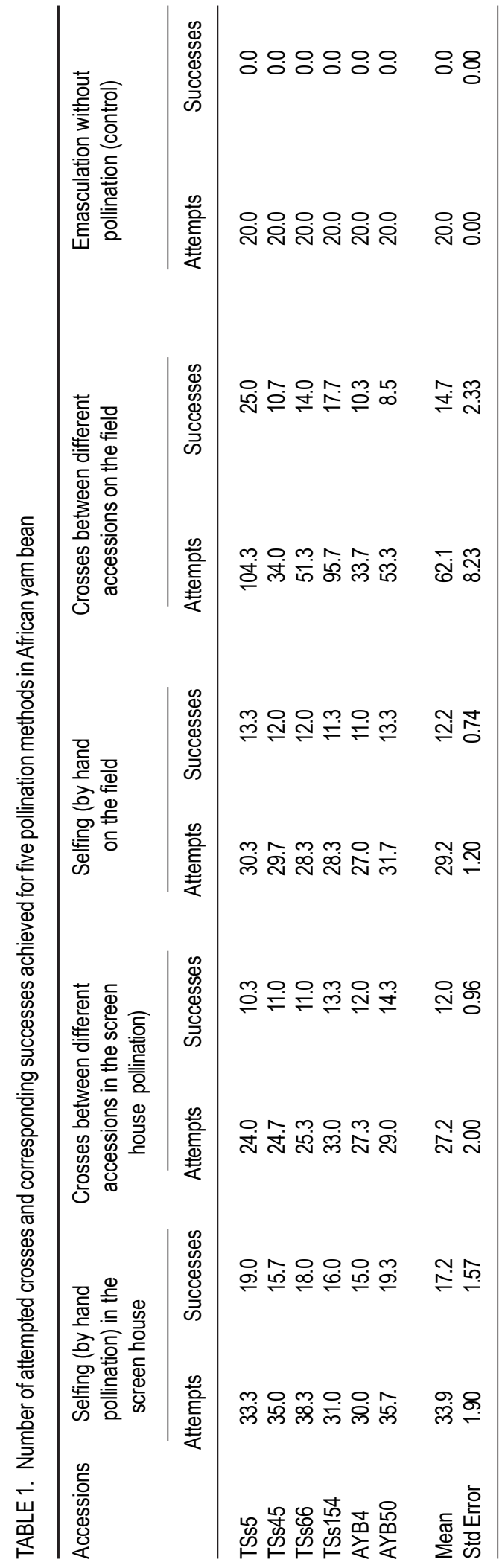


TABLE 2. Fruit set (\%) of six accessions of African yam bean in five pollination methods

\begin{tabular}{|c|c|c|c|c|c|c|c|}
\hline Accessions & $\begin{array}{l}\text { Open- } \\
\text { pollinated }\end{array}$ & $\begin{array}{l}\text { Selfed Isolated } \\
\text { in net bags }\end{array}$ & $\begin{array}{l}\text { Selfed by hand } \\
\text { screen house }\end{array}$ & $\begin{array}{l}\text { Selfed by } \\
\text { hand field }\end{array}$ & $\begin{array}{c}\text { Genetic crosses } \\
\text { screen house }\end{array}$ & $\begin{array}{l}\text { Genetic crosses } \\
\text { field }\end{array}$ & $\begin{array}{l}\text { Emasculated } \\
\text { not pollinated }\end{array}$ \\
\hline TSs5 & $63.2 \pm 5.7^{a}$ & $49.3 \pm 4.7^{\mathrm{a}}$ & $54.7 \pm 10.8^{a}$ & $43.6 \pm 3.1^{a}$ & $42.6 \pm 2.3^{a}$ & $22.5 \pm 10.1^{a}$ & 0.0 \\
\hline TSs45 & $47.4 \pm 5.4^{\mathrm{a}}$ & $28.7 \pm 3.2^{\mathrm{cd}}$ & $45.8 \pm 1.9^{a}$ & $42.8 \pm 11.5^{\mathrm{a}}$ & $44.4 \pm 4.2^{\mathrm{a}}$ & $32.5 \pm 7.8^{a}$ & 0.0 \\
\hline TSs66 & $51.5 \pm 7.9^{a}$ & $32.9 \pm 0.7^{b c}$ & $45.6 \pm 2.9^{a}$ & $38.3 \pm 2.5^{\mathrm{a}}$ & $43.9 \pm 4.0^{\mathrm{a}}$ & $29.9 \pm 7.7^{a}$ & 0.0 \\
\hline TSs154 & $52.5 \pm 4.6^{a}$ & $36.3 \pm 8.6^{b}$ & $53.9 \pm 11.3^{\mathrm{a}}$ & $39.3 \pm 3.9^{a}$ & $42.2 \pm 6.5^{\mathrm{a}}$ & $18.6 \pm 8.0^{\mathrm{a}}$ & 0.0 \\
\hline AYB4 & $46.7 \pm 9.8^{a}$ & $24.4 \pm 3.7^{d}$ & $50.0 \pm 0.0^{a}$ & $40.7 \pm 5.4^{a}$ & $43.6 \pm 1.9^{a}$ & $30.8 \pm 5.9^{a}$ & 0.0 \\
\hline AYB50 & $46.6 \pm 4.2^{\mathrm{a}}$ & $37.3 \pm 6.3^{b}$ & $53.4 \pm 8.9^{a}$ & $42.3 \pm 12.9^{a}$ & $47.0 \pm 12.2^{\mathrm{a}}$ & $28.6 \pm 8.7^{a}$ & 0.0 \\
\hline Mean & 51.3 & 34.8 & 50.7 & 41.2 & 43.9 & 27.0 & 0.0 \\
\hline Std error & 2.71 & 2.16 & 1.71 & 1.69 & 1.30 & 2.06 & 0.00 \\
\hline \multicolumn{8}{|c|}{ Means followed by the same letters are not significantly different at $5 \%$ level of probability using Least significant difference (LSD) } \\
\hline Accessions & $\begin{array}{l}\text { Open- } \\
\text { pollinated }\end{array}$ & $\begin{array}{l}\text { Selfed (Isolated } \\
\text { in net bags) }\end{array}$ & $\begin{array}{l}\text { Selfed by hand } \\
\text { (screen house) }\end{array}$ & $\begin{array}{l}\text { Selfed by } \\
\text { hand (field) }\end{array}$ & $\begin{array}{r}\text { Genetic crosses } \\
\text { (screen house) }\end{array}$ & $\begin{array}{c}\text { Genetic crosses } \\
\text { (field) }\end{array}$ & $\begin{array}{l}\text { Emasculated } \\
\text { (not pollinated) }\end{array}$ \\
\hline TSs5 & $63.2 \pm 5.7^{\mathrm{a}}$ & $49.3 \pm 4.7^{\mathrm{a}}$ & $50.4 \pm 13.1^{\mathrm{a}}$ & $43.6 \pm 3.1^{\mathrm{a}}$ & $34.6 \pm 7.6^{\mathrm{a}}$ & $22.4 \pm 10.1^{\mathrm{a}}$ & 0.0 \\
\hline TSs45 & $47.4 \pm 5.4^{\mathrm{a}}$ & $28.7 \pm 3.2^{\mathrm{bc}}$ & $40.8 \pm 9.9^{a}$ & $40.2 \pm 11.5^{\mathrm{a}}$ & $40.9 \pm 5.1^{\mathrm{a}}$ & $32.5 \pm 7.8^{\mathrm{a}}$ & 0.0 \\
\hline TSs66 & $51.5 \pm 7.9^{a}$ & $32.9 \pm 0.7^{\mathrm{bc}}$ & $46.8 \pm 5.2^{\mathrm{a}}$ & $42.8 \pm 2.5^{\mathrm{a}}$ & $44.0 \pm 10.9^{a}$ & $29.9 \pm 7.7^{\mathrm{a}}$ & 0.0 \\
\hline TSs154 & $52.5 \pm 4.6^{a}$ & $36.3 \pm 8.6^{b}$ & $42.6 \pm 26.5^{a}$ & $39.3 \pm 3.9^{a}$ & $39.9 \pm 9.9^{a}$ & $18.6 \pm 8.0^{a}$ & 0.0 \\
\hline AYB4 & $46.7 \pm 9.8^{\mathrm{a}}$ & $24.4 \pm 3.7^{c}$ & $50.0 \pm 0.0^{\mathrm{a}}$ & $40.7 \pm 5.4^{a}$ & $47.5 \pm 3.8^{a}$ & $30.8 \pm 5.9^{a}$ & 0.0 \\
\hline AYB50 & $46.6 \pm 4.2^{\mathrm{a}}$ & $37.3 \pm 6.3^{b}$ & $54.1 \pm 10.9^{a}$ & $42.3 \pm 12.9^{a}$ & $47.9 \pm 20.8^{\mathrm{a}}$ & $28.6 \pm 8.7^{a}$ & 0.0 \\
\hline Mean & 51.3 & 34.8 & 47.4 & 41.2 & 42.5 & 27.0 & 0.0 \\
\hline Std error & 2.71 & 2.16 & 1.88 & 1.69 & 2.48 & 2.06 & 0.00 \\
\hline
\end{tabular}

Means followed by the same letters are not significantly different at $5 \%$ level of probability using Student-Newman-Keuls (SNK) Test 
TABLE 3. Seed set of four pollination methods and reproductive biology estimates in six African yam bean accessions

\begin{tabular}{|c|c|c|c|c|c|c|c|c|c|}
\hline \multirow[t]{2}{*}{ Accessions } & \multicolumn{5}{|c|}{ Seed set $(\%)$} & \multicolumn{4}{|c|}{ Reproductive Biology estimates (\%) } \\
\hline & $P_{x f d}$ & $P_{0}$ & $P_{\text {sfd }}$ & $P_{x s h}$ & $P_{\text {ssh }}$ & IS & $|S|$ & $S$ & $\mathrm{~T}$ \\
\hline TSs 5 & 88.91 & 93.02 & 93.28 & 97.61 & 90.98 & 89.58 & 2.26 & 94.05 & 5.95 \\
\hline TSs 45 & 90.29 & 92.52 & 92.60 & 91.59 & 99.22 & 88.39 & 1.34 & 96.54 & 4.33 \\
\hline TSs 66 & 92.37 & 94.59 & 94.97 & 92.29 & 93.46 & 91.23 & 1.49 & 85.38 & 14.62 \\
\hline TSs 154 & 91.67 & 93.44 & 93.58 & 95.51 & 93.26 & 92.92 & 2.41 & 92.67 & 7.33 \\
\hline AYB 4 & 90.18 & 91.79 & 91.88 & 91.68 & 97.62 & 93.19 & 1.33 & 94.71 & 5.29 \\
\hline AYB 50 & 89.06 & 91.09 & 91.45 & 94.77 & 88.32 & 82.06 & 1.84 & 84.94 & 14.23 \\
\hline Mean & 90.18 & 92.49 & 92.92 & 94.06 & 94.13 & 88.91 & 1.77 & 91.38 & 8.62 \\
\hline
\end{tabular}

Where:

$S=$ Pxfd - Po/Pxfd - Psfd

$P_{\text {xfd }}=$ the value from crossing on the field,

$\mathrm{p}_{\mathrm{sfd}}=$ the value from selfing on the field,

$P_{\text {ssh }}=$ the value from selfing in the screenhouse,

$P_{x s h}=$ the value from crossing in the screenhouse, and

$P_{0}=$ the value from open pollination.

IS = the value from isolation (artificial selfing)

ISI-Index of self incompatibility = Fruit set from self-pollination (by hand) $/$ Fruit set from cross-pollination .

$T=1-S$. Where $T=$ the outcrossing rate and $S$ is the selfing rate.

percentage (SSP) was highest in the selfed accessions on the field, followed by the open pollinated accessions. The isolated accessions had the least SSP $(88.91 \%)$. Accessions selfed and crossed in the screen house had high seed sets $(94.13$ and $94.06 \%)$ respectively,

Self-incompatibility, selfing and outcrossing. The index of self-incompatibility (ISI), selfing and outcrossing for the various accessions is presented in Table 3 . The ISI ranged from 1.33 to 2.26. The selfing rate was highest in TSs 45 (96.54\%). The outcrossing rate obtained in this study ranged from 4.33 (TSs45) to 14.62 (TSs66) (Table 3). Insect pollinators such as the bumblebee were observed pollinating AYB flowers on the field (Fig. 2).

Paired T-test comparison. Paired T- test was used to compare means of the fruit and seed-sets among four categories of pollination studied in all possible combinations (Table 4). Significant differences $(\mathrm{P}<0.05)$ were obtained in the paired
T test of the FSP and SSP among the different categories of pollination evaluated (Table 4). The seed-set between open pollinated accessions and accessions emasculated, and crossed with pollen grains from another accession as well as those isolated with net bags were significant $(\mathrm{p}<0.05)$.

Germination and vigour. Germination and vigour data of the seeds obtained from open pollinated, isolated and selfed pollinations are presented (Table 5). Germination was highest in the open pollinated accessions and least in accessions isolated in net bags. Accessions TSs5 and TSs45 had the highest germination $(90.0 \%)$. The germination and vigour percentages of seeds obtained from accessions crossed in the screenhouse and on the field are presented (Table 6). Germination and vigour were high in both cases. Vigour was higher for seeds obtained from crosses in the screen house compared to accessions crossed on the field. 


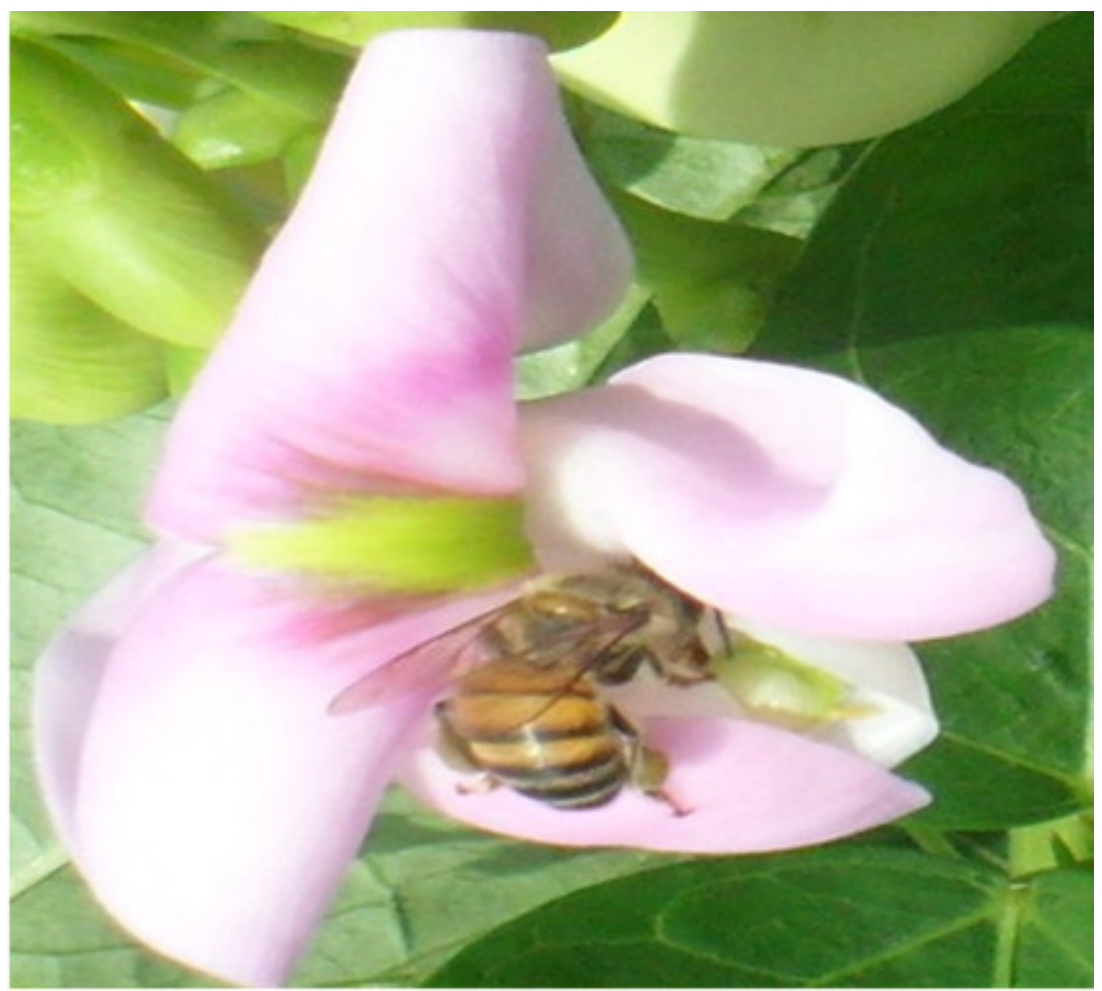

Figure 2. Pollination of African yam bean flower by a bumblebee

TABLE 4. Mean comparison by paired t-test of the fruit set and seed set (\%) among the various categories of pollination

\begin{tabular}{|c|c|c|c|c|}
\hline Parameters (\%) & Category pair & Mean \pm S.E & $\mathrm{t}$ value & $\operatorname{Pr}>\| t \mid$ \\
\hline \multicolumn{5}{|l|}{ Fruitset } \\
\hline & $A-B$ & $24.44 \pm 3.45$ & 7.07 & $<.0001^{* \star *}$ \\
\hline & $A-C$ & $12.73 \pm 2.36$ & 5.39 & $0.003^{* *}$ \\
\hline & $A-D$ & $9.42 \pm 4.53$ & 2.08 & 0.090 \\
\hline & $B-C$ & $-7.31 \pm 3.32$ & -2.20 & $0.042^{*}$ \\
\hline & $B-D$ & $-8.38 \pm 4.53$ & -1.85 & 0.123 \\
\hline & $C-D$ & $-3.31 \pm 4.96$ & -0.67 & 0.534 \\
\hline \multicolumn{5}{|l|}{ Seed set } \\
\hline & $A-B$ & $2.18 \pm 1.07$ & 2.02 & $0.0485^{\star}$ \\
\hline & $A-C$ & $3.92 \pm 1.39$ & 2.81 & $0.007^{* *}$ \\
\hline & $A-D$ & $-0.55 \pm 0.80$ & -0.69 & 0.501 \\
\hline & $B-C$ & $1.99 \pm 1.58$ & -2.42 & 0.215 \\
\hline & $B-D$ & $-2.32 \pm 0.96$ & -1.41 & $0.027^{*}$ \\
\hline & $C-D$ & $-5.72 \pm 1.55$ & -1.79 & 0.130 \\
\hline
\end{tabular}

$A=$ Unemasculated flowers left for open pollination

$B=$ Emasculated flowers, crossed with pollen grains from another accession

$C=$ Unemasculated flowers enclosed (isolated) with fine mesh transparent net before flowering commences and throughout the flowering period (Artificial selfing).

$D=$ Plant with emasculated flowers, crossed with pollen grains from the same accession (Selfing by hand)

Significant probability values are presented in bold ${ }^{*}-\mathrm{P}<0.01,{ }^{* *}-\mathrm{P}<0.01{ }^{* * *} . \mathrm{P}<0.001$ S.E $=$ Standard error 
TABLE 5. Germination and vigour percentages of seeds obtained from three pollination methods

\begin{tabular}{|c|c|c|c|c|c|c|}
\hline \multirow[t]{3}{*}{ Accessions } & \multicolumn{6}{|c|}{ Pollination methods } \\
\hline & \multicolumn{2}{|c|}{ Open pollinated } & \multicolumn{2}{|c|}{ Isolated with nets } & \multicolumn{2}{|c|}{ Selfed by hand } \\
\hline & TDG (\%) & TDV (\%) & TDG $(\%)$ & TDV (\%) & TDG (\%) & TDV (\%) \\
\hline TSs5 & 90.00 & 68.35 & 43.33 & 47.93 & 51.67 & 40.00 \\
\hline TSs45 & 90.00 & 54.29 & 50.00 & 49.11 & 76.67 & 65.28 \\
\hline TSs66 & 75.00 & 56.31 & 80.00 & 86.84 & 80.00 & 62.50 \\
\hline TSs154 & 73.33 & 66.62 & 76.67 & 83.68 & 46.67 & 64.45 \\
\hline AYB4 & 81.67 & 75.61 & 70.00 & 78.33 & 76.67 & 42.23 \\
\hline AYB50 & 78.33 & 63.12 & 41.67 & 66.67 & 73.33 & 68.26 \\
\hline Mean & 81.39 & 64.05 & 60.28 & 68.76 & 67.50 & 57.12 \\
\hline
\end{tabular}

TDG-Ten days germination TDV-Ten days vigour

TABLE 6. Germination and vigour percentages of seeds obtained from accessions crossed in the screenhouse and on the field

\begin{tabular}{lccccc}
\hline \multirow{2}{*}{ Reciprocal crosses } & \multicolumn{2}{c}{ Screenhouse } & & \multicolumn{2}{c}{ Field } \\
\cline { 2 - 3 } \cline { 5 - 6 } Male Female & TDG (\%) & TDV (\%) & & TDG $(\%)$ & TDV (\%) \\
\hline TSs5 X AYB50 & 61.7 & 77.7 & & 80.0 & 66.7 \\
TSs45X TSs66 & 86.7 & 77.1 & & 81.7 & 92.2 \\
TSs66 X TSs45 & 86.7 & 85.1 & & 65.0 & 65.0 \\
TSs154 XAYB4 & 71.7 & 76.5 & & 80.0 & 68.2 \\
AYB4 X TSs154 & 78.3 & 92.3 & & 73.3 & 76.5 \\
AYB50 X TSs 5 & 63.3 & 100.0 & & 85.0 & 82.8 \\
Mean & 74.7 & 84.8 & 77.5 & 75.2 \\
\hline
\end{tabular}

TDG-Ten days germination, TDV-Ten days vigour

\section{DISCUSSION}

Fruits and seeds were set in four breeding methods-open-pollinated, genetic crosses between accessions, genetic crosses within accessions and isolated accessions in fine mesh bags. No fruit or seed set was obtained in accessions emasculated, but not pollinated in the screenhouse. This may indicate the absence of apomixis in Sphenostylis stenocarpa. Apomixis is the ability of a plant to bypass the most fundamental aspects of sexual reproduction: meiosis and fertilisation. Without the need for male fertilisation, the resulting seed germinates and a plant develops as a maternal clone (Melanie et al., 2014). It is a genetically controlled reproductive process which occurs in more than 120 angiosperm genera (Carman, 1997). However, no major seed crop species are apomictic, and attempts to introduce the apomixis trait to crops from apomictic relatives by cross-pollination have been largely unsuccessful (Savidan, 2000). Apomixis makes it possible to produce maternal clones and rapidly fix desirable genotypes in crop species, which could accelerate agricultural breeding strategies (Melanie et al., 2014). The average FSP of $51.32 \%$ obtained from the openpollinated breeding method was higher than the other breeding methods tested and confirmed by Adewale (2011) that the open-pollinated breeding 
method produces more fruit sets than the other tested breeding methods. Intraspecific reciprocal crosses between accessions in the screen house and on the field had low fruit set percentages. Contrary to the report of Popoola et al. (2011), that all flowers of outcrossed accessions were lost, fruits and seeds were set in outcrossed accessions in our study. It was observed that when TSs 5 was used as female parent and AYB50 as pollen donor, most pollination produced fruits, while in the opposite direction this was not the case. This behaviour could be regarded as unilateral incompatibility which occurs when pollen tubes fertilises the ovules in a cross in one direction but are inhibited in the stigma, style or ovary in the reciprocal cross, as described by Onus and Pickersgill (2004). The high seed sets obtained from accessions selfed and crossed in the screen house could be due to the environmental factors in the screen house.

African yam bean undergoes autonomous selfing because the unmanipulated flowers isolated with net bags in each accession had the ability to set fruits and seeds. The significantly higher fruit and seed sets obtained in crosses between the same accessions may be an indication of self compatibility in the species. Similar observation was made by Adewale (2011). It, however, contradicts the report of Chourykaew et al. (2004) who observed zero fruit set for Afgekia sericea (Fabaceae), with the exclusion of pollinators. The rate of fruit set from artificial self-pollination was greater than $30 \%$ in the field and the screen house, which shows that the species is highly self compatible in accordance to the ranking of Dafni (1992). The pollination success in the self pollination method (by hand) was higher than that of artificial self-pollination (isolation in fine mesh net bags). Average selfing rates of $91.38 \%$ and outcrossing rate of $8.62 \%$ were obtained. This result is in agreement with that of Adewale (2011), who obtained selfing and outcrossing rates of 90 and $10 \%$, respectively. However, it is contrary to the report of Popoola et al. (2011) that AYB is an obligate selfer.

African yam bean therefore, exhibits both selfing and outcrossing. The variation observed in the outcrossing rates of the six accessions investigated in our study could be due to the pollination environment since it can radically change the actual outcrossing rate of a selfcompatible species, regardless of the timing of selfing (Lloyd, 1992). For example, if pollinators visit early selfing species, then outcrossing rates will increase especially if outcross pollen also arrives early (Lloyd, 1992; Lloyd and Schoen, 1992; Kalisz et al., 2012). The proportion of outcrossing and selfing in a population depends in part, on self incompatibility mechanisms, floral development, and pollinator behavior (Richards, 1986; Kittleson and Maron, 2000). Temporal separation of male and female reproductive phases increases the probability that outcrossing occurs in self-compatible species (Richards, 1986; Kittleson and Maron, 2000). Nevertheless, the proximity of pollen to the stigma and the receptiveness of the stigma to viable pollen could enhance autonomous selfing to occur frequently (Lloyd and Schoen, 1992).

Tropical forage legumes reproduce generally by autogamy, however; many also present high levels of cross-pollination. Chiari et al. (2010) using RAPD markers showed that tropical legume forages, Stylosanthes capitate, in Brazil presented 31\% outcrossing (Chiari et al., 2010). Various other legumes presented from $4 \%$ outcrossing in Desmodium heterocarpon to 23\% in Centrosema gyroides (Jank et al., 2011). Becerra and Lloyd (1992) identified improvements in the fruit setting efficiency of species when visited by pollinators. The observation of insect pollinators mainly the bumble bee pollinating AYB flowers on the field, confirmed the report of Adewale (2011) that papilionaceous flowers are also bee pollinated. According to Sorensen (1996), all species of yam bean (Pachyrhizus species) are self-pollinating but some levels of outcrossing have been reported $(2-4 \%)$. The highest incidence occurred in $P$. ahipa, depending on the availability of pollinators, mainly different bumblebee species.

The index of self-incompatibility (ISI) ranged from 1.33 to 2.26, with an average of 1.77 . According to Dafni (1992), if the ISI value is greater than 1, the gametes are self- compatible. Based on this, the gametes of Sphenostylis stenocarpa flowers can be classified as selfcompatible. Variation was observed in the ISI values for fruit set between accessions of AYB studied. 
The germination and vigour percentages differed in the four breeding methods studied with germination been highest in the open pollinated accessions and vigour been highest in crosses between accessions in the screen house. Environmental factors could be responsible for the variation in germination and vigour obtained. The germination and vigour percentages obtained in our study were lower than that obtained by Adewale (2011). This could be due to variability in the six accessions studied for testa hardness or poor viability of the seeds.

\section{CONCLUSION}

This study has shown that Sphenostylis stenocarpa exhibits both selfing $(91.38 \%)$ and outcrossing $(8.62 \%)$, but could also be insect pollinated. The four breeding methods studied had the ability to set fruit and seeds. Therefore, successful crossing within and between accessions of AYB is possible. This is useful for genetic improvement of the species with beneficial genes from the wild relatives.

\section{ACKNOWLEDEMENT}

This research was sponsored by the Genetic Resources Centre of the International Institute of Tropical Agriculture, Ibadan, Nigeria.

\section{REFERENCES}

Adewale, B.D. 2011. Genetic diversity, stability and reproductive biology of African yam bean Sphenostylis stenocarpa (Hochst. Ex. A. Rich.) Harms. PhD thesis, Federal University of Agriculture, Abeokuta, Nigeria.

Adewale, B., Daniel, A. and Aremu, C.O. 2013. The nutritional potentials and possibilities in

African yam bean for Africans. International Journal of Agricultural Science 3(1): 8-19.

Becerra, J.X. and Lloyd, D.G. 1992. Competition dependent abscission of self-pollinated flowers of Phormum tenax (Agavaceae): A second action of self-incompatibility at whole flower level? Evolution 46:458-469.

Carman, J.G. 1997. Asynchronous expression of duplicate genes in angiosperms may cause apomixis, bispory, tetraspory, and polyembryony. Biological Journal of the Linnean Society 61: 51-94.

Charlesworth, D. and Charlesworth, B. 1987. Inbreeding depression and its evolutionary

consequences. Annual Review of Ecology and Systematics 18:237-268.

Chiari, L, Resende, R.M.S. and Matida, E.T. 2010. Mating system parameters in Stylosanthes guianensis (Aubl.) Sw. based on RAPD markers. African Journal of Biotechnology 9:5820-5822.

Chinedu, S.N. and Nwinyi, C.O. 2012. Proximate analysis of Sphenostylis stenocarpa and Voadzeia subterranean consumed in South Eastern Nigeria. Journal of Agricultural Biotechnology and Sustainable Devevelopment 4(3): 57 - 62.

Chourykaew, B., Khunwasi, C., Boonkerd, T. and Seelanan, T. 2004. Floral visitors and fruit set in Afgekia sericea Craib (Fabaceae). The Natural History Journal of Chulalongkorn University 4(2): 31-44.

Dafni, A.1992. Pollination ecology: A practical approach. Oxford University Press, Oxford.

Fasoyiro, S.B., Ajibade, S.R., Omole, A.J., Adeniyan, O.N. and Farinde, E.O. 2006. Proximate, minerals and antinutritional factors of some under-utilized grain legumes in southwestern Nigeria. Nutrition Food and Science 36(1):18-23.

Frankel, R. and Galum, E. 1997. Pollination mechanism, reproduction and plant breeding. Springer Verlay Berlin 3-4.

IITA, 2012. Standard Operation Procedures (SOP) for IITA Seedbank, International Institute of Tropical Agriculture, Ibadan, Nigeria. Pp. 37.

Jank, L., Valle, C.B. and Resende, R.M.S. 2011. Breeding tropical forages. Crop Breeding and Applied Biotechnology S1: 27-34.

Kalisz, S., Randle, A., Chaiffetz, D., Faigeles, M., Butera, A. and Beight, C. 2012. Dichogamy correlates with outcrossing rate and defines the selfing syndrome in the mixed-mating genus Collinsia. Annals of Botany 109:571582.

Karoly, K. 1992. Pollinator limitation in the facultatively autogamous annual, Lupinus nanus (Leguminosae). American Journal of Botany 79:49-56. 
Karron, J.D. 1987. A comparison of levels of genetic polymorphism and self incompatibility in geographically restricted and widespread plant congeners. Evolutionary Ecology 1:4758.

Kittelson, P.M. and Maron, J.L. 2000. Outcrossing rate and inbreeding depression in the perennial yellow bush Lupine, Lupinus Arboreus (Fabaceae) American Journal of Botany 87: (5) 652-660.

KIu, G.Y.P., Amoatey, H.M., Bansa, D. and Kumaga, F.K. 2001. Cultivation and use of African yam bean (Sphenostylis stenocarpa) in the Volta Region of Ghana. Journal of Food Technology in Africa 6:74-77.

Lloyd, D.G. 1992. Self- and cross-fertilization in plants. II. The selection of self-fertilization. International Journal of Plant Science 153:370-380.

Lloyd, D.G. and Schoen, D.J. 1992. Self and crossfertilization in plants. I. Functional dimensions. International Journal of Plant Science 153: 358-369.

Melanie, L.H, Anna, M. and Koltunow, G. 2014. The Genetic Control of Apomixis: Asexual Seed Formation. Genetics 197 (2): 441-450.

Onus, A.N, and Pickersgill, B. 2004. Unilateral incompatibility in Capsicum (Solanaceae): Occurrence and taxonomic distribution. Annals of Botany 94: 289-295.

Popoola, J.O., Adegbite, A.E., Obembe, O.O. and Agbolade, J.O. 2011. Reproductive mechanisms and pollen characterization in some accessions of an underutilized legume: (Sphenostylis stenocarpa Hochst Ex. A. Rich) harms. International Journal of Biodiversity and Conservation 3 : (6) 185-192.

Potter, D. 1992. Economic botany of Sphenostylis (Leguminosae). Economic Botany 46:262-275.

Richards, A.J. 1986. Plant breeding systems. George Allen and Unwin, London. pp. 529.

Saka, J.O., Ajibade, S.R., Adeniyan, O.N., Olowoyo, R.B. and Ogunbodede, B.A. 2004. Survey of underutilized grain legume production systems in south-west agricultural zone of Nigeria. Journal of Agricultural Food Information $6:$ ( 2/3) 93-108.

SAS, 2010. User's Guide. Basic version 9.3, SAS institute Cary, North Carolina, USA

Savidan, Y. 2000. Apomixis: Genetics and Breeding, pp. 13-86. In: Plant Breeding Reviews. Janick, J. (Ed.). Wiley, New York.

Sorensen, M. 1996. Yam bean (Pachyrhizus DC.). Promoting the conservation and use of underutilized and neglected crops. 2. Institute of Plant Genetics and Crop Plant Research, Gatersleben/ International Plant Genetic Resources Institute, Rome. Available online at: http://www.bioversityinternational.org/ uploads/tx_news/Yam_bean__Pachyrhizus _DC._311.pdf

Takebayashi, N. and Morrell, P.L. 2001. Is selffertilization an evolutionary dead end? Revisiting an old hypothesis with genetic theories and a macro evolutionary approach. American Journal of Botany 88 (7): 1143-1150.

Togun, A.O. and Egunjobi, J.K. 1997 Reproductive development and seed yield in African yam bean. Nigerian Journal of Science 2:29-35. 